\title{
The Impact of Entrepreneurship Education in Higher Education: A Systematic Review and Research Agenda
}

\author{
GHULAM NABI \\ Manchester Metropolitan University, United Kingdom
}

FRANCISCO LIÑÁN

University of Seville, Spain, and Anglia Ruskin University, United Kingdom

ALAIN FAYOLLE

EM LYON Business School, France

NORRIS KRUEGER

University of Phoenix, United States, and Entrepreneurship Northwest, United States

ANDREAS WALMSLEY

Plymouth University, United Kingdom

Using a teaching model framework, we systematically review empirical evidence on the impact of entrepreneurship education (EE) in higher education on a range of entrepreneurial outcomes, analyzing 159 published articles from 2004 to 2016. The teaching model framework allows us for the first time to start rigorously examining relationships between pedagogical methods and specific outcomes. Reconfirming past reviews and meta-analyses, we find that $E E$ impact research still predominantly focuses on short-term and subjective outcome measures and tends to severely underdescribe the actual pedagogies being tested. Moreover, we use our review to provide an up-to-date and empirically rooted call for less obvious, yet greatly promising, new or underemphasized directions for future research on the impact of university-based entrepreneurship education. This includes, for example, the use of novel impact indicators related to emotion and mind-set, focus on the impact indicators related to the intention-to-behavior transition, and exploring the reasons for some contradictory findings in impact studies including person-, context-, and pedagogical model-specific moderators.

Prof. Fayolle, Prof. Krueger, and Prof. Walmsley made an equal contribution to the paper. The authors thank Associate Editor Prof. Siri Terjesen and the anonymous reviewers for providing constructive and helpful guidance throughout the review process. We also thank Prof. Béchard, Prof. Henry, and Prof. Solomon for their comments on earlier drafts of this paper, and Dr. Christina Purcell and Imran Akhtor for their technical support.

Address all correspondence to: Dr. Ghulam Nabi, Department of Management, Business School, All Saints Campus, Oxford Road, Manchester, M15 6BH, UK. Email: G.Nabi@mmu.ac.uk
Since the first entrepreneurship course at Harvard Business School was delivered in 1947, entrepreneurship education (EE) programs in higher education have grown rapidly and globally (Kuratko, 2005; Solomon, 2007). This growth reflects increasing recognition that university-based EE programs (hereafter referred to as EE programs) promise to support a range of potential entrepreneurial outcomes (Nabi 
\& Liñón, 2011; Rideout \& Gray, 2013). For example, enhanced student venture creation skills, knowledge, and attitudes (Greene \& Saridakis, 2008) and graduate business start-ups and overall job creation (Greene, Katz, \& Johannisson, 2004; Rideout \& Gray, 2013) ultimately contributing to economic growth and development (Bosma, Acs, Autio, Coduras, \& Levine, 2008).

Synthesizing this fast-growing body of empirical research and reviews on EE outcomes suggests three main patterns. First, reviews highlight a focus on short-term, subjective impact measures such as entrepreneurial attitudes and intentions, rather than longer term ones such as venture creation behavior and business performance, and call for future research to address this gap (e.g., Garavan \& O'Cinneide, 1994; Henry, Hill \& Leitch, 2005; Pittaway \& Cope, 2007). Promoting and implementing EE programs entails substantial investment of time and resources, so it is critically important to take stock of what we currently know about the range of EE outcomes and provide benchmarks for further research.

Second, recent reviews suggest that the impact of EE programs on attitudes and behavior is equivocal because studies suggest both positive and negative outcomes (Dickson, Solomon, \& Weaver, 2008; Fayolle, 2013; Martin, McNally, \& Kay, 2013; Thompson, JonesEvans, \& Kwong, 2010). These reviews tend to argue that the contradictory findings of EE impact studies may be due in part to methodological or statistical artifacts such as cross-sectional survey methodology and lack of control groups; notably, Rideout and Gray's (2013) review and recent meta-analytical studies by Martin et al., (2013) and Bae, Qian, Miao, and Fiet (2014). However, also likely are other substantial reasons for the contradictory findings in EE impact research that can be teased out with single studies/interventions: for example, the nature and context of pedagogical interventions as well as contextual factors. In their extensive 1970-2004 review of EE research, Pittoway and Cope (2007) conclude there is a lack of research that directly links student/graduate entrepreneurial outcomes to different pedagogical methods and call for deeper investigation. Pedagogical methods may emphasize, for example, "exploration, discussion, or experimentation (e.g., library, web or other interactive searches, labs, field trips, simulations)" (Béchard \& Grégoire, 2005:111).

As well as examining a range of EE impact measures, it is therefore necessary to examine the different pedagogical methods that underpin them, not just methodological issues. Confusion regarding the impact of EE may result from the wide diversity of pedagogical methods employed in EE programs (Fretschner \& Weber, 2013). This is further complicated by the lack of detail on pedagogical interventions studied (Martin et al., 2013), and the need for a stronger, more theory-driven framework for assessing the impact of such interventions (cf. Baptista \& Naia, 2015; Fayolle \& Gailly, 2008; Krueger, 2015; Lackéus, 2015; Neergaard, Tanggaard, Krueger, \& Robinson, 2012). It is therefore important to take stock of research on the pedagogy-entrepreneurial outcomes link within a coherent framework.

Third, few reviews focus on EE specifically in higher education. Notable exceptions are Pittaway and Cope (2007) and Rideout and Gray (2013), but the former is limited to data from over a decade ago and the latter focuses on articles until 2010/2011. We cover 100 articles published in the past 5 years, which have not been covered in previous reviews of university-based EE impact (e.g., Rideout \& Gray, 2013) or meta-analyses of EE outcomes of education in general (e.g., Martin et al., 2013). There is still, therefore, a need for a current review that focuses on EE pedagogy and outcomes in higher education.

These three distinct yet related research gaps form the rationale for this article. Our aim is to review systematically the empirical evidence on the impact of higher education-based EE published in the last decade. Using the teaching model framework outlined below, we focus on assessing the range of EE outcomes in impact studies. A secondary aim is to examine the extent of the relationship between the pedagogical methods used and the specific outcomes achieved. While the former offers a broad overview of the evidence of EE impact, the latter explores whether the mixed results in impact studies are related to different pedagogical methods. To advance understanding of how to research EE impact, we need both.

We believe that the main strength of our work here is the adoption of an integrated teaching model framework (Figure 1) to offer a coherent, overarching theoretical structure that covers both a broad range of entrepreneurial outcomes and pedagogical methods (Béchard \& Grégoire, 2005; Fayolle \& Gailly, 2008). Our teaching model framework integrates a range of impact measures and pedagogies. This is particularly useful here because for the first time we can now evaluate not only the range of EE outcomes in higher education impact studies, but also any patterns that connect specific types of pedagogical methods and impact measures. Our 


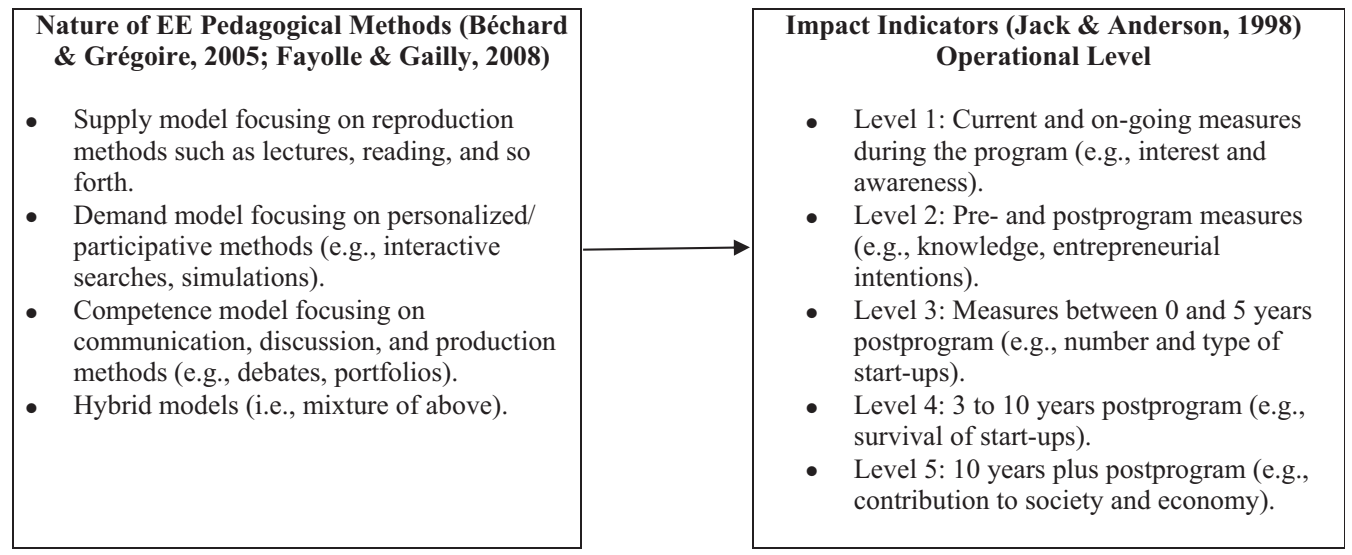

FIGURE 1

An Integrated Teaching Model Framework Encompassing EE Impact and Underpinning Pedagogy

framework therefore permits empirical review with a pedagogical slant and responds to calls for more rigorous research to explore reasons for the contradictory findings in EE research (cf. Martin et al., 2013). The teaching model approach provides critical grounding for researchers and practitioners in the field of EE.

\section{Conceptual Framework}

Pedagogical research highlights how the evaluation of impact should be a key dimension of any teaching program and therefore needs to be considered at the program design stage (Fayolle \& Gailly, 2008). In our research, types of EE impact have been integrated into the broader context of a teaching model framework (Béchard \& Grégoire, 2005, 2007; Fayolle \& Gailly, 2008). We explore two dimensions in our review-types of impact and underpinning pedagogy - given the paucity of research that directly links student/graduate entrepreneurial outcomes to different pedagogical methods (Pittaway \& Cope, 2007).

In the absence of $\alpha$ single impact measure within the teaching model framework, Henry, Hill, and Leitch (2003, building on Jack \& Anderson, 1998) propose an impact classification system (incorporating several types of impact measures) that can be employed to assess the level of impact of EE programs. This classification system draws on earlier research on entrepreneurship (Block \& Stumpf, 1992) and educational impact (Kirkpatrick, 1959), and complements the impact dimension of the teaching model framework because it highlights a range of impact measures from the beginning to the end of an EE program and beyond (see Figure 1 for a more detailed explanation), thereby providing a basis for the systematic evaluation of EE impact studies.

Reflection on different types of EE impact measures raises the issue of underpinning pedagogical methods. Béchard and Grégoire (2005) address this issue through identifying three "archetypical" teaching models in higher education: the supply model, the demand model, and the competence model, plus two hybrid teaching models. The supply model focuses on pedagogical methods highlighting a behaviorist paradigm, in terms of the "transmission and reproduction of knowledge and application of procedures" (e.g., lectures, reading, watching/listening; Béchard \& Grégoire, 2005: 111). The demand model focuses on pedagogical methods highlighting a subjectivist paradigm, involving personalized meaning through participation in terms of "exploration, discussion and experimentation" (e.g., library use, interactive searches, simulations; Béchard \& Grégoire, 2005: 111). The competence model focuses on pedagogical methods, highlighting an interactionist theoretical paradigm, in terms of active problem solving in reallife situations, where "teaching is conceived as a strategic intervention to allow for-and influence-how students organize the resources at their disposal (e.g., knowledge, abilities) into competences that can be mobilized for action" (Béchard \& Grégoire, 2005: 115-116). This model focuses on methods emphasizing "communication and discussion" (e.g., seminar, presentations, debates) and knowledge "production" (e.g., essays, modeling, portfolios).

In contrast to the supply model, which emphasizes a behaviorist perspective, both the demand and competence models fit within the constructivist 
approach to EE (Löbler, 2006; Neergaard et al., 2012). Behaviorism assumes learning is primarily the passive transfer of knowledge from the teacher to the student, while constructivism assumes that learning involves actively participating in the construction of new understanding. Often, pedagogical methods in EE in higher education are highly behaviorist: lectures, homework, quizzes, and so forth, that focus on knowledge acquisition, rather than the deeply experiential approaches of the constructivist perspective (Neergaord et al., 2012). Béchard and Grégoire (2005) apply these teaching models (supply, demand, competence) in EE to a higher education context. This allows us to classify and analyze various pedagogical models and review empirical evidence on the link between EE pedagogy and impact.

\section{Systematic Review Methodology}

We analyze $159 \mathrm{EE}$ impact studies published from 1 February 2004 to 2 January 2016, continuing where Pittaway and Cope's (2007) study left off. Following best practice from the methodological (Tranfield, Denyer, \& Smart, 2003), synthesis (Cooper, 1989; Fink, 2009), and entrepreneurship literature (Pittaway \& Cope, 2007; Wang \& Chugh, 2014), we use a "systematic review process." Initially, we use the root word "education" to search through all 11 entrepreneurship journals listed in the Association of Business Schools (ABS) as medium- and high-ranking entrepreneurship journals (Horvey, Kelly, Morris, \& Rowlinson, 2010). ${ }^{1}$ We then use three databases (ABI ProQuest, Emerald, and Science Direct) to search for a broader range of keywords/search terms. The highest number of hits were from search terms including "entrepreneurship education," "higher education," "pedagogy," "educational interventions," "graduate," "undergraduate," or Boolean variations of these terms and an extensive range of others.

Only article citations that met the following criteria were included: (a) empirical in nature rather

\footnotetext{
${ }^{1}$ The ABS incorporates blind peer-reviewed journals for ranking entrepreneurship journals and expert assessment of journal quality (Harvey et al., 2010). Our 11 ABS journals include: Journal of Business Venturing, Entrepreneurship Theory and Practice, Journal of Small Business Management, International Small Business Journal, Small Business Economics, Entrepreneurship and Regional Development, Strategic Entrepreneurship Journal, Family Business Review, Journal of Small Business and Enterprise Development, International Journal of Entrepreneurial Behaviour and Research, and Venture Capital: An International Journal of Entrepreneurial Finance.
}

than purely conceptual; (b) peer-reviewed published journal articles rather than working/conference papers or unpublished material; (c) primarily focused on higher education in terms of entrepreneurship education (or elements thereof) and its empirical impact on entrepreneurship outcomes (broadly defined to include both attitudinal and behavioral outcomes); (d) sampled recipients of EE from higher education institutions (rather than primary/secondary school, or nonhigher education level); and (e) analyzed primary rather than secondary data (Bae et al., 2014 and Martin et al., 2013 were included because of their use of meta-analysis, but reviews or research agendas were excluded).

We also added searches for articles from bibliographies, key authors, and Google Scholar, as well as checking relevant references in recent reviews of EE outcomes (e.g., Bae et al., 2014; Martin et al., 2013; Rideout \& Gray, 2013). We screened these additional candidates using our selection criteria. For example, Martin et al. (2013) includes articles that are unpublished or focus on schoolchildren, and were therefore excluded from our review. ${ }^{2}$ Two coauthors independently read the original collection of articles. We identified two first-order themes: (1) Types of Impact and (2) Pedagogical Methods. We then identified second-order themes by mapping our articles onto Henry et al.'s (2003) classification for impact measures (Levels 1 to 5) and Béchard and Grégoire's (2005) framework of pedagogical models (e.g., supply, demand, and competence). For example, traditional lectures and business plan writing suggested a supply model, active participation in seminars, events or out-of-class projects reflected a demand model, and real-life entrepreneurial situations indicated $\alpha$ competence model.

\section{REVIEW FINDINGS: THEMES AND TRENDS}

We begin by examining background characteristics of our articles. This is useful when interpreting general patterns, for example, the most prominent journal outlets, country contexts, and types of students/graduates. We then analyze our articles regarding types of $E E$ impact and relationships between types of impact and different pedagogical methods.

\footnotetext{
${ }^{2}$ Further examples of excluded articles (with reasons for exclusion) are available from the authors.
} 


\section{Background Characteristics of the Data Set}

Our sample covers research published in 61 journals, predominantly in entrepreneurship and small business journals (39\%) and management and education journals (47\%). The eight journals publishing the most EE impact articles account for 86 out of the 159 articles $(54 \%){ }^{3}$

Overall, the majority of our articles were published in the last 5 years and are dominated by European, undergraduate, and entrepreneurship/ business student samples. A majority are from 2011 onward (100 articles, 63\%) and were not covered in previous reviews or meta-analyses (e.g., Martin et al., 2013; Rideout \& Gray, 2013). Data comes from 38 countries, dominated by Europe (81 articles, $51 \%$, especially the UK with 28/18\%); US (27/17\%); Asia (26/ $16 \%)$; and then followed by Africa (16/10\%); Australia (2/1\%); and international comparisons (5/3\%). Students in our sample are mostly undergraduate (53\%) or postgraduate $(12 \%)$, or alumni or unspecified university students. The majority studied entrepreneurship and business (35\%) or business combination courses $(24 \%)$.

\section{Types of Impact}

In the articles reviewed (see Table 1), we distinguish between studies focusing largely on our framework's (see Figure 1) lower level impact indicators (typically short-term/subjective indicators at Levels 1 and 2) and on higher level ones (typically longer term/objective indicators at Level 3 or above). More specifically, the most common impact indicators are related to lower level indicators of subjective/ personal change: attitude (32 articles), skills and knowledge (34 articles), perceived feasibility (42 articles), and entrepreneurial intention (81 articles). By contrast, higher level indicators of longer term, objective, or socioeconomic impact are much less frequent: 21 articles study start-ups and 8 articles consider venture performance, both typically within 10 years of the program. Last, 41 articles report results not falling into any of these categories. These articles measure impact in terms of other variables, such as subjective norms (Souitaris, Zerbinati, \&

\footnotetext{
${ }^{3}$ Education + Training (3l articles), The International Journal of Management Education (12), Journal of Small Business and Enterprise Development (10), International Journal of Entrepreneurial Behavior \& Research (9), Journal of Small Business Management (7), International Entrepreneurship and Management Journal (6), International Small Business Journal (6), Academy of Management Learning \& Education (5).
}

Al-Laham, 2007), dispositional optimism (Crane, 2014), or satisfaction with the EE program (Rae \& WoodierHorris, 2012).

Most articles in the review claim a positive link between an EE program and subjective (e.g., personal change) or objective (e.g., business start-up activity) impact indicators (205 instances overall, see Table l). Regarding lower level impact indicators, the most common indicator by for is entrepreneurial intentions (Level 2 in our framework). Most of the reviewed articles (61 articles out of 81,75\%) report a positive link between EE and participants' start-up intentions. Nonetheless, several studies report mixed, negative, or nonsignificant/ambiguous results for the link with entrepreneurial intentions (18 articles or $22 \%$, see Table 1). Of these, some articles suggest that EE reduces entrepreneurial intention for certain groups, for example, male German students (Packham, Jones, Miller, Pickernell, \& Thomas, 2010), female Finish students (Joensuu, Viljamaa, Varamäki \& Tornikoski, 2013), Greek students (Petridou \& Sarri, 2011), students with previous entrepreneurial exposure (Fayolle, Gailly, \& Lassas-Clerc, 2006b), or students with a weaker entrepreneurial university culture (Wang \& Verzat, 2011). Our results suggest we know considerably more about the direct EE-intentions relationship in general than about the moderating role of gender (e.g., Joensuu et al., 2013; Shinnar, Hsu, \& Powell, 2014), culture- (e.g., Bernhofer \& Han, 2014; Crone, 2014), or context-specific patterns (e.g., Piperopoulos \& Dimov, 2015; Turker \& Selçuk, 2009), with only nine studies focusing clearly on such relationships.

Further, using a meta-analysis of 73 studies, Bae et al. (2014) report a small but significantly positive EE-entrepreneurial intentions relationship, but that cultural values act as a moderator. For example, a high collectivistic culture or a low uncertainty avoidance culture reinforces the impact of EE. They also report that after controlling for pre-education entrepreneurial intentions, the EE-intentions relationship is not significant nor is gender a significant moderator. Although their research does not focus specifically on the impact of EE in higher education (they look at average effects across all education levels), we include them here because their findings provide some indicative evidence.

Compared to entrepreneurial intentions (51\%), far fewer studies exist on the relationship between EE and other subjective impact indicators (Levels 1 and 2 of our framework) including psychological variables such as attitude (20\%, e.g., Boukamcha, 2015; Chang, Benamraoui, \& Rieple, 2014; Vorley \& Williams, 2016); 


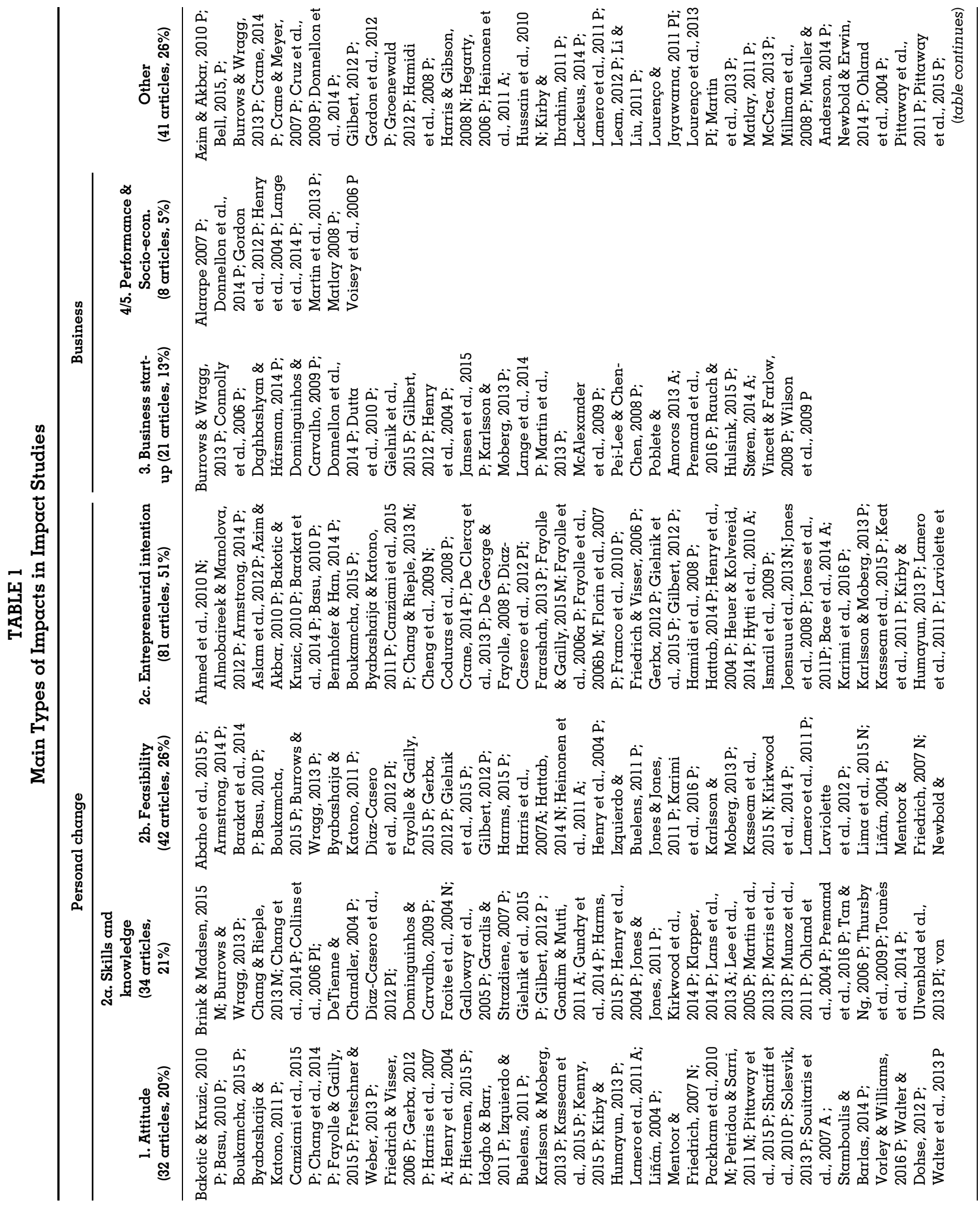




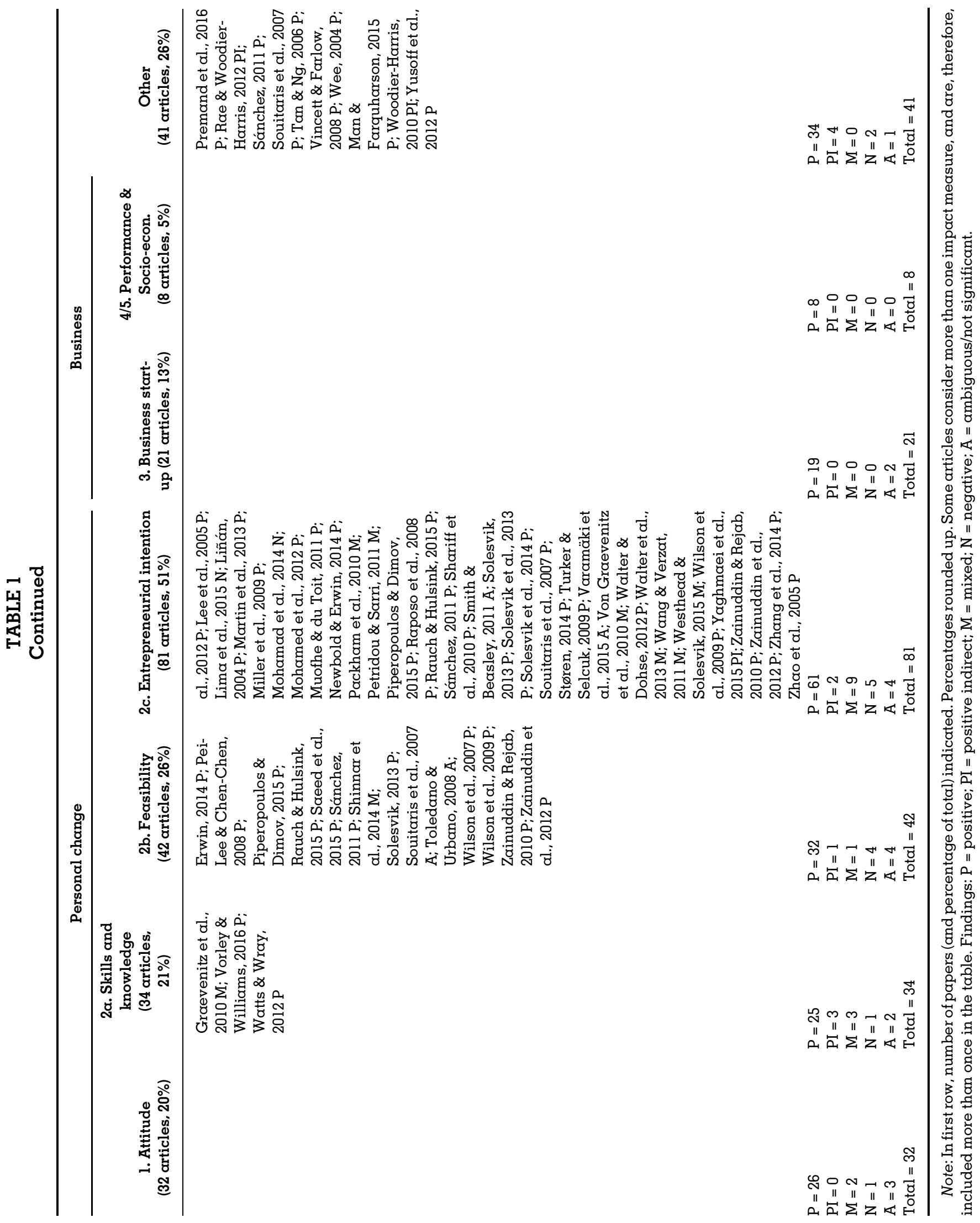


perceived feasibility (26\%, e.g., Rauch \& Hulsink, 2015; or skills and knowledge (21\%., e.g., Burrows \& Wragg, 2013; Premand, Brodmann, Almeida, Grun, \& Barouni, 2016). Most studies suggest a positive link between the program and these variables, but some articles report results that are not significant or negative. These include, for example, the absence of a significant link between EE and entrepreneurial attitudes among Spanish students (Lanero, Vózquez, Gutiérrez, \& García, 2011), and a negative link between EE and attitudes toward entrepreneurship among South African students (Mentoor \& Friedrich, 2007), or perceived entrepreneurial and management skills among British students (Chang \& Rieple, 2013). So again, limited studies explore the context-specificity of EE's impact.

Novel ways of assessing EE impact in higher education are limited. Only four studies explore emotion or related approaches to assessing EE impact. For example, inspiration (not learning) emerges as the most important benefit of EE, implying a "change of heart" as well as a positive link to entrepreneurial intentions (Souitoris et al., 2007). A few other studies also suggest a positive EE-outcomes link regarding uncertainty and ambiguity tolerance (Lackéus, 2014); dispositional optimism (Crone 2014); and sense of psychological ownership (Man \& Farquharson, 2015). Similarly, four studies focus on EE impact on intention-to-nascent start-up activity or entrepreneurial identity. These suggest either a nonsignificant impact of EE on nascency (Souitaris et al., 2007), or a positive link through a dynamic process of internal self-reflection and social engagement (Donnellon, Ollila, \& Middleton, 2014; Lackéus, 2014), and personal development, for example, a multiple sense of responsibility, independent thinking, and connecting to one's own and others' needs (Mueller \& Anderson, 2014). Other emotion- or transition-based indicators are also completely absent from our review. For example, outside of our review, research highlights EE's role in developing the importance of entrepreneurial passion (intense positive emotion and drive, see Cardon, Wincent, Singh, \& Drnovsek, 2009), yet it is strikingly missing from the articles in our review.

Our review suggests 29 instances (corresponding to 25 articles, see Table 1) focusing on objective impact indicators, typically over a longer timeframe corresponding to the higher Levels 3 (0-5 years), 4 (3-10 years), or 5 (over 10 years) in our fromework. Because these types of studies are limited in our review, some examples are given. Such studies include the positive impact of undergraduate (Pei-Lee \& Chen-Chen, 2008) and postgraduate (Dominguinhos \& Carvalho, 2009) EE programs on start-up rates at Level 3 of our framework. Furthermore, Lange, Marram, Jawahar, Yong, and Bygrave (2014) provide a notable example of the long-term positive impact of $\mathrm{EE}$ on Babson graduate performance over a 25-year period, including a major economic contribution, for example, 1,300 new full-time businesses were started, with average annual revenues of $\$ 5.5$ million and an average of 27 employees. Last, using a meta-analytical approach (including pre-and posteducation data, $N=$ 16,657), Martin et al. (2013) found small but positive relationships between $\mathrm{EE}$ and entrepreneurial outcomes incorporating nascent behavior, and start-up and venture performance (e.g., financial success and personal income). As with Bae et al., (2014), they do not specifically focus on higher education (they look at average effect across all educational levels), but we include them here because their findings provide some indicative evidence. Most of our higher impact studies report a positive link between EE and objective indicators, but one suggests a relationship that is not significant. Using a sample of 2,827 university graduates in Norway, Støren (2014) reports graduates who have had EE are not more frequently selfemployed than other graduates. Thus, our review suggests high-impact studies are scarce and need not show positive impact.

A final finding relates to the measurement methodology of the articles. Typically, articles use crosssectional survey methodology (68\%). Nonetheless, some notable exceptions employ a longitudinal design and/or a control group. These generally demonstrate a pattern of positive EE impact for entrepreneurial intentions (Souitaris et al., 2007), competencies (Sónchez, 2011), and start-ups (Karlsson \& Moberg, 2013). However, even in more methodologically rigorous studies, a few still report a lack of significant results for entrepreneurial self-efficacy (Souitaris et al., 2007) or significantly negative impact on entrepreneurial attitudes (Mentoor \& Friedrich, 2007). Overall, the review suggests reasonable evidence of positive EE impact. This holds especially for entrepreneurial attitudes and intentions (impact Levels 1 and 2 of our framework), but even here some examples demonstrate differential impact depending on context and the background of participants (Fayolle \& Gailly, 2015; Foyolle et al., 2006b).

\section{Pedagogical Methods Underpinning Impact}

Next, we examine the extent of the relationship between the pedagogical methods used and the 


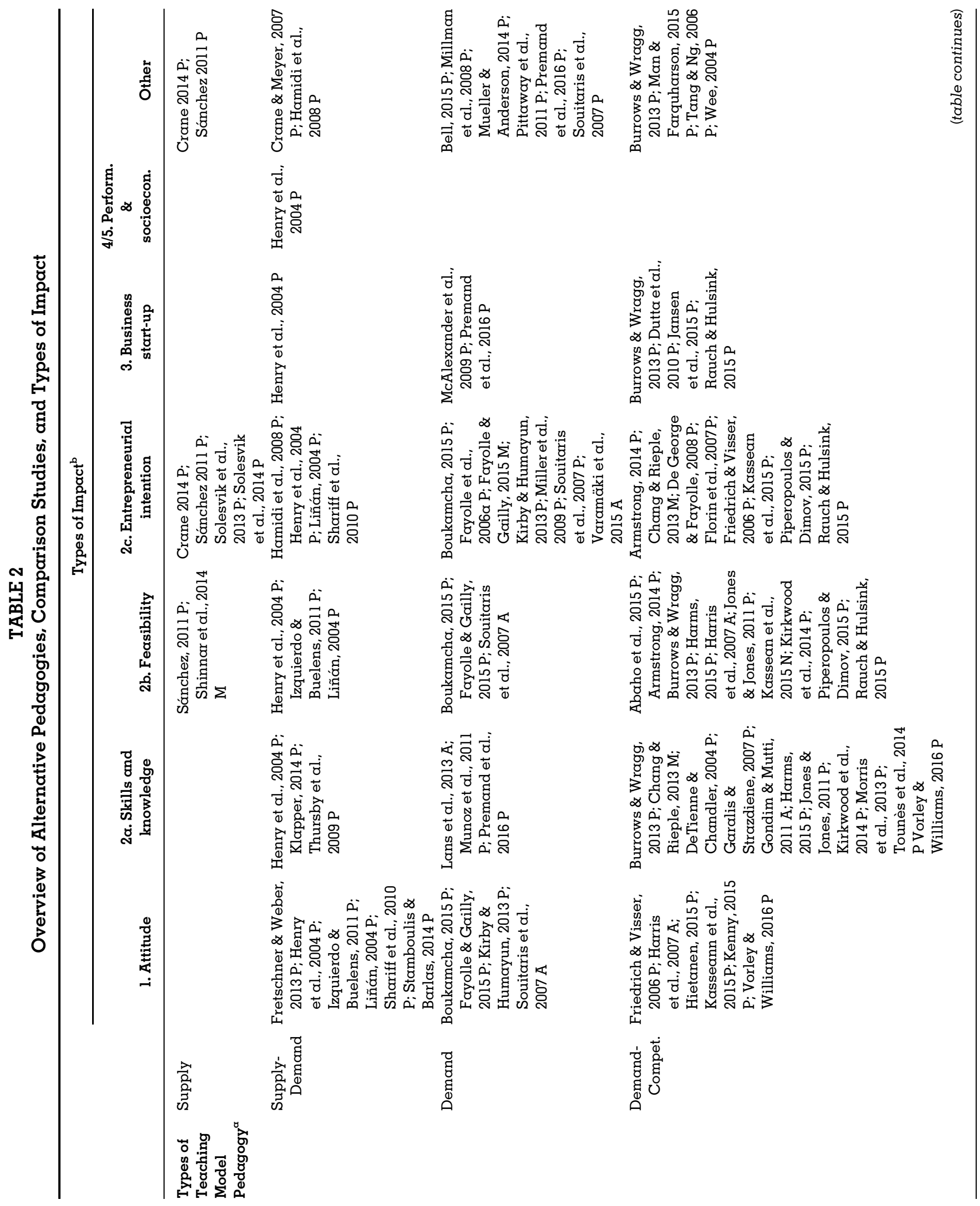




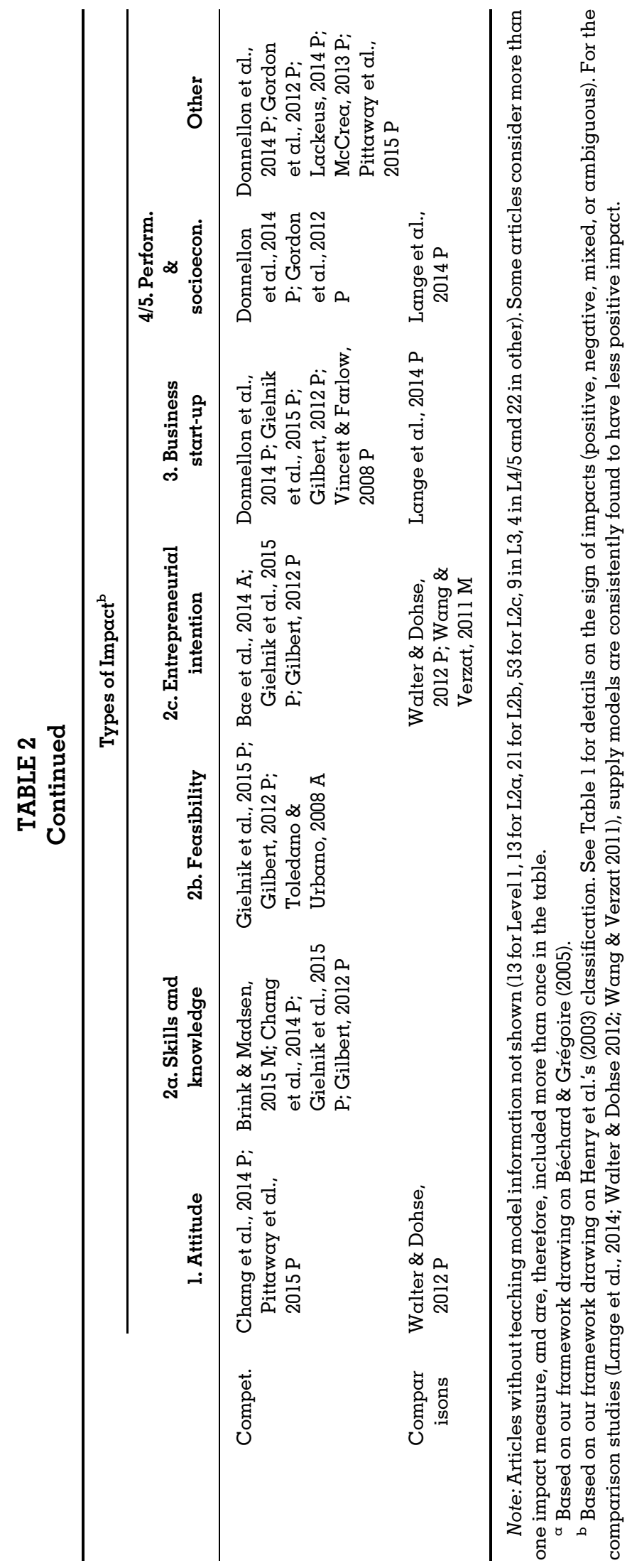


specific outcomes achieved (see Table 2). In our review, studies that provide sufficient pedagogical detail are limited. Only 72 of our 159 articles (45\%) provide enough detail for us to determine their pedagogical approach. The following section focuses on these 72 articles.

\section{Supply and Supply-Demand Model Pedagogy}

Only five articles can be classified in terms of supply model pedagogy. These are positively related to self-efficacy (Sónchez, 2011) and entrepreneurial intentions (e.g., Crane, 2014; Solesvik et al., 2013, 2014). For example, Sónchez (2011) focuses on transmitting knowledge to students so that they "know about entrepreneurship," and this mainly behaviorist course has a positive impact on a range of student perceptions (at Level 2 of our framework, e.g., intention, self-efficacy). This suggests a supply model link to lower level impact indicators, although Shinnar et al., (2014) find mixed results, primarily at Level 2, based on a moderating effect of gender. In turn, programs that combine pedagogies from the supply and demand model tend to be positively related to lower levels of our framework. Of the 12 supply-demand articles, only one (Henry et al., 2004) addresses impact at higher levels. A typical example of a supply-demand article is the program analyzed by Hamidi, Wennberg, and Berglund (2008) which despite concentrating on knowledge transmission, includes some experiential learning, in this case, creativity development exercises whereby the authors report a positive link with entrepreneurial intentions.

\section{Demand and Demand-Competence Model Pedagogy}

Fifteen articles analyze interventions adhering to demand model pedagogy. These typically focus on short-term intensive experiential programs (e.g., Fayolle \& Gailly, 2015), or longer experiential residential-based programs (e.g., Boukamcha, 2015). They also include student-led entrepreneurship clubs that allow students to work on collaborative projects and gain awareness from experienced entrepreneurs (Pittaway, Rodríguez-Falcon, Aiyegbayo, \& King, 2011), and a pedagogical method that goes beyond formal classroom teaching, incorporating, for example, network events and interaction with entrepreneurs (Souitaris et al., 2007). All these studies share a focus on exploration, discussion, and experimentation, with a preoccupation on students' needs and interests. Moreover, these studies largely suggest a positive link of this model's pedagogy with lower level impact indicators-our framework's Level 2 indicators (entrepreneurial intention, Fayolle et al., 2006a; Souitaris et al., 2007), or other personal change, such as satisfaction with the course or participation (Millman, Matlay, \& Liu, 2008; Pittaway et al., 2011).

Of the EE programs studied in the review, 27 are consistent with demand-competence model pedagogy. They share the inclusion of an important element of realism, such as real-life problems to be solved. This is powerful, because despite the challenges to the learner, the learning is more transferable to the real world (cf. outside our review, Neergaard et al. 2012). In the articles in this stream, the pedagogical methods are experiential and entail working side by side with, for example, entrepreneurs (e.g., Chang \& Rieple, 2013); realistic entrepreneurial exercises (e.g., Gondim \& Mutti, 2011); starting and running a "real" business (e.g., Burrows \& Wragg, 2013); and problem-based learning (e.g., Kirkwood, Dwyer, \& Gray, 2014). Again, these studies report a positive link with lower level impact measures (skills and knowledge, and feasibility, e.g., Jones \& Jones, 2011). However, ambiguous or mixed results are also found for intention and feasibility (Chang \& Rieple, 2013; Harris, Gibson, \& Taylor, 2007). Overall, the pattern suggests a positive link between demand and demand-competence model pedagogy and primarily lower level impact indicators.

\section{Competence Model Pedagogy}

Twelve articles fall into this category. Pedagogical methods entail students who are starting up businesses by consulting external experts, typically for legal, accounting, and sales help (Vincett \& Farlow, 2008) or dealing with real-world problems or opportunities in industry-engaged environments to enhance social interaction and deeper learning (Gilbert, 2012). These articles are positively related to Level 2 (skill development, learning; Gilbert, 2012), Level 3 (actual start-ups; Gilbert, 2012; Vincett \& Forlow, 2008), and Level 4 of our framework (positive changes in the person and business that run 5 years after the course: e.g., increase in social capital and socioeconomic bonds; Gordon, Hamilton, \& Jack, 2012). Given the limited number of articles in this category, we see our results as indicative rather than confirmatory. 


\section{Comparison Studies}

Only three articles compare EE programs using competing pedagogical methods. Lange et al. (2014) suggest that experiential courses (featuring demand and competence models) better predict multiple entrepreneurial behaviors: The rare behaviorist courses in their study ("how to write a business plan") are essentially a negative predictor. They measure impact at the highest impact level of our framework (Level 5) and show a positive socioeconomic impact up to 25 years postprogram. Similarly, Walter and Dohse (2012) compare active learning (constructivist) to traditional learning (behaviorist) in locations with either weak or already-strong entrepreneurial cultures, finding the constructivist model to have a stronger impact in terms of, for example, entrepreneurial intention.

Overall, our review highlights that each category of pedagogical methods (supply, demand, competence, hybrids) has some positive relationship with the lower level impact indicators of our teaching model framework (e.g., attitudes and intentions). However, the demonstrated pattern of pedagogy impact depends to an extent on the aims of researchers. Although orticles featuring fewer experiential programs (supply, supply-demand, demand) focus more on basic or lower levels of our framework, articles examining more experiential programs (demand-competence and competence) also focus on impact at higher levels (e.g., actual start-ups and socioeconomic impact over time). These latter studies ask more from their programs and typically obtain higher impact.

\section{DISCUSSION}

Guided by a unique, theory-driven teaching model framework, we undertook a systematic review of a range of EE impacts in higher education, drawing on empirical evidence published since 2004. This entailed a thematic analysis of the evidence using our adopted teaching model framework to classify different types of outcomes and pedagogies. We also explored the extent of the relationship between pedagogical methods and outcomes achieved.

\section{Reaffirmation of Past Reviews}

Despite the increase in the amount of research on EE and entrepreneurial outcomes in higher education over the past 12 years (nearly two thirds of our 159 articles are published in the last 5 years), there is still a general focus on lower level, short-term, subjective impact indicators, especially the EEentrepreneurial intentions link (51\%), and the lack of specifying even minimal pedagogical detail (55\%). Hence, in general, we reconfirm the findings and repeat the calls of previous reviews for more research on entrepreneurial behavior (e.g., Pittaway \& Cope, 2007) and greater pedagogical detail (cf. Martin et al., 2013). Our teaching model framework urges a focus on higher level impacts such as startups, firm survival rates, business performance, and societal contribution. Furthermore, it also means that future researchers provide detailed information about the pedagogical methods, so we can understand the impact of pedagogical designs and methods.

Extending previous reviews, our findings lead us to focus on new or underemphasized calls for future research. As a general pattern from our findings, progress on the previous calls outlined above has been slow, and EE impact research continues to be limited. For example, in our review, it is rare to see articles on novel EE impact measures or exploring the reasons behind the contradictory findings in higher education-based $\mathrm{EE}$ research that go beyond statistical/artifactual reasons (cf. Martin et al., 2013; Rideout \& Gray, 2013). Table 3 presents our recommendations for future research and these are discussed in more detail below.

\section{Types of EE Impact}

\section{Focus on Novel Impact Indicators Related to Emotion-Based Approaches}

Given the dominance of entrepreneurial intentions as an impact indicator in our research, we suggest it is important to understand alternative impact measures. Although entrepreneurship is considered a "journey of the heart" and the importance of understanding entrepreneurial emotion (affect, emotions, feelings), especially during the new venture creation process is acknowledged (Cardon, Foo, Shepherd, \& Wiklund, 2012), there is surprisingly little empirical research in our review that focuses on emotion-based impact indicators. We therefore urge scholars to pursue the following important avenues.

First, we are surprised by the scarcity of research that addresses emotion or affect. Given the growing consensus on their importance in entrepreneurial 
TABLE 3

\section{Future Research Directions: Types of EE Impact and Pedagogical Models}

\section{Reaffirmation of past reviews}

1. Ongoing requirement for increased research on higher level impact indicators by examining objective and higher level measures at Levels 4 and 5 of our teaching model framework (see Figure 1) including entrepreneurial behavior.

2. More detail about the specifics of the pedagogy in impact studies.

New or underemphasized research directions

1. Types of Impact

A. Focus on novel impact indicators related to emotion-based and mind-set approaches

i. Explore role of EE program-derived inspiration in higher education as an impact indicator and a mediator between EE and a range of other impact measures. For example, does inspiration mediate the EE-behavior relationship?

ii. Examine the development of the entrepreneurial mind-set in higher education such as dispositional optimism, uncertainty and ambiguity tolerance.

B. Focus on impact indicators related to the intention-to-behavior transition

i. Build on Souitaris et al. (2007) to generate new knowledge about why there is (or is not) a transition from entrepreneurial intentions into nascent or start-up behavior, specifically for example, why do some recipients of higher education-based EE with high entrepreneurial intentions start up their own businesses after graduating, while others (despite high intentions) do not? What is the role of EE in higher education in this process?

ii. Explore the development of entrepreneurial identity in higher education.

C. Explore contextual reasons for some contradictory findings in impact studies

i. Explore individuals' background in terms of previous entrepreneurial exposure and pre-educational intentions to clarify the impact of higher education-based EE.

ii. Directly examine if the impact of EE programs in higher education on a range of entrepreneurial outcomes is gender-specific and for which outcomes.

iii.Consider contextual factors in higher education, e.g., type of course, type of institution.

iv. Expand existing research by looking at relationship between culture and national context in EE impact studies. For example, how do cultural values moderate the impact of EE on outcomes? What outcomes are culture specific? Our teaching model framework could be expanded to incorporate culture-specific frameworks (e.g., Hofstede, 2003; Schwartz, 2004).

v. Explore underexamined fast-growing/emerging countries/continents in our sample e.g., Brazil, Russia, Africa, and Australia.

vi. Examine double-moderator interaction effects. For example, does EE impact outcomes as a function of culture and gender?

2. Pedagogical methods underpinning impact

A. Investigate competence model-related pedagogical methods to determine if they are truly more effective than other models, and why they are effective.

B. Building on our teaching model framework, directly compare and contrast a broad range of pedagogical models (supply, demand, competence, and hybrids) in terms of their impact on a range of impact indicators (from Levels 1 to 5).

\section{General recommendations}

1. Explore EE at other levels, i.e. other than higher education.

2. Explore impact of university-based EE on stakeholders other than students and graduates. For example, university faculty, donors/ investors, and community.

thinking, for example, passion (Cardon et al., 2009, 2012; Gielnik et al., 2015), this is startling. For example, only one empirical study in our sample measures EE program-derived entrepreneurial inspiration (Souitaris et al., 2007) that identifies emotional inspiration (not learning or incubation resources) as the most important EE "programme benefit" with inspiration also positively related to entrepreneurial intentions (Souitaris et al., 2007). Moreover, they define it as " $\alpha$ change of hearts (emotion) and minds (motivation) evoked by events or inputs from the programme and directed towards considering becoming on entrepreneur" (Souitaris et al., 2007: 573). Thus, we consider it of central importance as both on impact indicator in its own right (i.e., if EE increases inspiration), and as a predictor of other impact measures. Indeed, Souitaris et al. (2007: 587) conclude: "Universities that want to assess the effectiveness of their programmes should capture not only how much their students learn about entrepreneurship or whether they are satisfied with the courses, but also whether they are inspired from the programme." Despite its importance, inspiration from EE programs in higher education remains an under-researched phenomenon and warrants further research attention. 
A second key knowledge gap centers on impact measures focusing on the development of the entrepreneurial mind-set, defined here as cognitive phenomena deeper than intent ${ }^{4}$ (Krueger, 2007, 2015; Lackéus, 2015). Few studies in our review even reference this phenomenon. One rare example (Crane, 2014) suggests dispositional optimism as a key indicator of EE impact because of its self-regulatory function and dealing with uncertainty and setbacks. They find their program improves such optimism, suggesting another fruitful avenue to explore. Similarly, under OECD's Entrepreneurship360 initiative, Lackéus (2015) identifies the importance of uncertainty/ambiguity tolerance as impact indicators for action-based EE programs that tie back to the issue of emotions in entrepreneurial thinking.

\section{Focus on Impact Indicators Related to the Intention-to-Behavior Transition}

Our findings also suggest a paucity of studies of EE in higher education that bridge the transition from intention to behavior, that is Levels 2 to 3 in our teaching model framework. This is an important avenue because intention does not always translate into entrepreneurial behavior and little is known about this transition. Indeed, Pittaway and Cope (2007: 498) conclude "what is not known ... is whether propensity or intentionality is turned into 'entrepreneurial behavior', either in its broad sense or when focused narrowly on venture creation." Although we re-emphasize their claim here, we also extend their call, by suggesting two specific avenues that we encourage more scholars to pursue.

First, our review suggests very little empirical attention on analyzing how entrepreneurial intention translates into nascent or start-up activities. Although this relationship is examined in our review regarding start-up activities for nascency after an EE program (e.g., Souitaris et al., 2007), the lack of a positive significant relationship (albeit via entrepreneurial intentions) suggests more research is required on how intention follows through to action (or not). For example, why do some recipients of EE with high entrepreneurial intentions start up their own businesses after graduating, while others (despite high intentions) do not? What is the role of $\mathrm{EE}$ in this process? Second, very few studies in our review analyze the development of entrepreneurial

\footnotetext{
"Education researchers often refer to "noncognitive skills" to differentiate from more surface level learning such as facts and rote-learned skills (e.g., Krueger, 2015).
}

identity, although we see hints that EE relates to personal development beyond knowledge and skill acquisition, for example, by a change in thinking style (Mueller \& Anderson, 2014), internal selfreflection, and external engagement (Donnellon et al., 2014; Lackéus, 2014). Given how little we know of how intent becomes behavior, this is exceptionally important for further research.

\section{Explore Contextual Reasons for Contradictory Findings: Background, Gender, and Culture}

As our results report, most papers suggest positive results between $E E$ and a broad range of impact indicators, but with some contradictory studies (consistent with Martin et al., 2013). These authors advance methodological concerns as an explanation of such contradictory results; however, it would be remiss not to also assess person- and context-specific factors.

Concerning student backgrounds, for those who have less exposure to entrepreneurship, the general effect tends to be positive, because they usually increase their entrepreneurial intention, attitudes, and self-efficacy by participating in the programs (e.g., Fayolle \& Gailly, 2015; Fayolle, Gailly, \& LassasClerc, 2006a; Sónchez, 2011). In contrast, for those students who already have entrepreneurial experience, family background, or high previous entrepreneurial intention, the effects are generally weaker and may even be negative (see, e.g., Fayolle et al., 2006b; Von Graevenitz, Horhoff, \& Weber, 2010). Similarly, Bae et al. (2014) found that after controlling for preeducational entrepreneurial intentions, the relationship between EE and postprogram entrepreneurial intentions is not significant. However, given that Bae et al.'s (2014) meta-analysis did not focus specifically on higher education, we encourage more studies to focus on the role of student background in this context.

Regarding students' background, gender-specific differences are also an important source of contradictory findings. Few studies in our review focus on the differential impact of EE for male and female students/graduates, although those that did identify gender-specific effects. For example, Wilson, Kickul, and Marlino (2007) show that EE has a stronger impact on self-efficacy among females than males. Other studies also suggest the impact of EE on entrepreneurial intentions is gender-specific (e.g., Joensuu et al., 2013; Packhom et al., 2010), although there are too few studies to indicate if this favors males or females. A controversial finding in Bae et al.'s (2014) article concludes that gender does not significantly moderate the EE-entrepreneurial intention 
relationship. However, Bae et al. (2014) did not specifically examine studies of $\mathrm{EE}$ in higher education (as we do), but rather looked at averages from a metaanalysis across educational levels. Furthermore, unlike Bae et al. (2014), we look at higher level impact in terms of entrepreneurial behavior. Although we did not find any reported gender-specific effects at this level, in our view, this does not mean that they do not exist, merely that studies have not specifically focused on these effects.

Looking at further aspects of context (e.g., type of program: optional or compulsory; type of institution), there is evidence from our review that initial positive attitudes toward entrepreneurship, which are, however, not fully formed, change once they are confronted with the complexities and pitfalls of business start-up during EE. In our review, Hytti, Stenholm, Heinonen, and Seikkula-Leino (2010) analyze the motivations of students taking a compulsory EE program, finding that students with intrinsic motivation report lower learning and less satisfaction with the course (they expected more). Those taking the program with extrinsic motivation express a greater degree of satisfaction. Similarly, Petridou and Sarri (2011) find that attitudes and intentions are raised by an EE program in a generalist university, but lowered in a technology institute. The latter can be explained by the realization of the complexities involved in starting up a technology venture.

Similarly, culture and national context are likely significant factors but rarely tested directly because almost all studies in our review focus on a singlecountry or culture (or at least do not investigate cultural differences). However, Bae et al.'s (2014) metaanalysis suggests some salient cultural dimensions, at least with respect to entrepreneurial intentions. For example, some national or cultural contexts may be higher on some cultural dimensions, on average, like uncertainty avoidance (level of comfortableness with uncertainty and ambiguity; Hofstede, 2003, also see Krueger, Liñón, \& Nabi's, 2013 Special Issue in this area). This suggests culture-specific moderators are worthy of further consideration. In addition, our sample is dominated by studies in the United Kingdom, United States, and Asia, but only 5\% are from the fast-growing emerging BRIC (Brazil, Russia, India, and China) economies. There are no studies from Russia or India, and Africa and Australia are also under-represented, suggesting such countries and continents are largely absent from studies.

Moreover, culture is also likely to exhibit interaction effects with other impact factors like gender as implied in a handful of our articles regarding culture- and gender-specific findings. Packham et al. (2010), for example, suggest findings that EE negatively relates to entrepreneurial intentions for male German students. This double-moderator effect is consistent with limited research outside our review, for example, Shneor, Camgöz, and Karapinar (2013), who look at gender effects in two cultural settings, while analysis of Culture $\mathrm{x}$ Gender effects is absent from the studies reviewed here.

Considering our discussion on how student background and context (the "audience" dimension of the teaching model; Fayolle \& Gailly, 2008) seem to explain contradictory findings in previous studies, future research in this field is especially promising. Knowing the background and the profile of the students (e.g., prior entrepreneurial knowledge and skills, motivators, gender) and context (e.g., type of program, type of institution, program and country context) can also lead to better design and implementation of EE programs, and ultimately to more efficient learning processes, environments, and hence, impact (Béchard \& Grégoire, 2005; Fayolle \& Gailly, 2008, 2015). It also opens the door for future impact research that is more mindful of potential moderating factors and exploring a range of related questions. For example, to what extent is the impact of EE programs in higher education on a range of entrepreneurial outcomes gender-, culture-, and context-specific? Which impact indicators in our framework are dependent on moderator effects and which are more universally applicable? Our teaching model framework could also be expanded to incorporate culture-specific frameworks (e.g., Hofstede, 2003; Schwartz, 2004) allowing further consideration of the impact of higher education-based EE programs in different international and cultural contexts.

\section{Pedagogical Methods Underpinning Impact}

\section{Pedagogical Reasons for Contradictory Findings: Differences in Pedagogical Methods}

Our review suggests that all the pedagogical methods (supply, demand, competence, hybrids) have positive impact at Levels 1 and 2 of our teaching model framework (e.g., attitudes and intentions). However, our reviewed studies suggest that pedagogical methods based on competence are better suited for developing higher level impact. The evidence suggests that competence model pedagogy is associated with both subjective measures at Level 2 (e.g., entrepreneurial intention), and objective ones at Levels 3 (e.g., actual start-ups up to 5 years 
postprogram) and 4 (longer term impact on business up to 10 years postprogram). To put it more simply, such deeper, more experiential pedagogies seem to have the most potential to have impact at higher levels because students focus on developing behavioral competency in solving problems in real-life entrepreneurial situations.

Our findings suggest that the use of different pedagogical methods is at least partially responsible for the inconsistent findings in impact studies. However, given that our findings are based on a partial sample of our population of articles, they are indicative rather than confirmatory. ${ }^{5}$ To the best of our knowledge, this is the first systematic review that uses a teaching model framework to assess the impact of EE. In our view, this provides novel and meaningful insights. EE makes strong claims to have significant impact and a strong bias toward experiential pedagogies. This review confirms that we need to focus strongly in this direction. For example, it is essential to expand research on competence-model-related pedagogical methods. Do they really have stronger impact than other models, especially at higher levels of our teaching model framework? How do they work regarding underlying processes?

\section{Focus on Comparison Studies to Compare Pedagogical Methods}

Our review reveals very few comparison studies that directly compare the impact of different pedagogical methods. Considering the growing number of $\mathrm{EE}$ programs and the growing demand to assess them, should we not ask for evidence of what pedagogical methods work, desired impact, and actual impact? We thus encourage researchers to compare types of impact across different teaching pedagogical methods. This is the only way for us to understand EE impact in on incremental and meaningful way.

Our review includes comparison studies that link EE pedagogical methods in higher education to a broad range of impact measures using a teaching model framework. However, comparison studies in our review only tend to compare pedagogical methods in a limited way (e.g., supply versus competence; Lange et al., 2014; Walter \& Dohse, 2012; Wang \& Verzat, 2011). In our review, we identify five different pedagogical models

\footnotetext{
${ }^{5}$ Reduced from 159 to 72 due to insufficient pedagogical information from $55 \%$ of our articles. Further, we suspect that it could be extremely valuable to assess the quality of pedagogy, not just its intended characteristics.
}

including hybrid versions (supply, supply-demand, demand, demand-competence, competence). We urge scholars of future comparison studies to directly compare the impact of a broader range of pedagogical methods using a teaching model framework. We believe that such a comparative approach offers great opportunities to explore a number of theoretically, practically, and empirically meaningful research questions that may help to explain the contradictory findings on the impact of higher education-based EE programs and increase generalizability. For example, what pedagogical models work for which types of impact and in which contexts? We encourage future researchers to rigorously isolate the impact of a pedagogical intervention, controlling for the context- and person-specific factors outlined earlier.

\section{Limitations and General Recommendations}

Three limitations of our review are noteworthy. First, we only cover $\mathrm{EE}$ in higher education, although $\mathrm{EE}$ also flourishes in high school programs, and adult (nondegree and non-academic) education. Focusing on other educational levels and means of delivery outside higher education was outside the scope of our research, but our findings do open the door for assessing EE impact at other levels.

Second, data on whether an individual is exposed to multiple training before, during, and after higher education is limited. However, some articles in our review do use more sophisticated research designs, for example, adopting a pretest-posttest control group design (e.g., Souitaris et al., 2007), or controlling for prior entrepreneurial exposure (e.g., Fayolle \& Gailly, 2015). Although focusing on methodological designs is outside the primary scope of our research and is covered elsewhere (e.g., Rideout \& Gray, 2013), we still include a range of articles with different methodologies in our research, and our findings confirm those of existing reviews with on emphasis on methodological rigor (e.g., Martin et al., 2013; Rideout \& Gray, 2013). Rather than reiterate the methodological weaknesses that other reviews found, we sought to identify perhaps less obvious, yet greatly promising new or underemphasized directions for future research.

Third, our review focuses on the recipients of university-based EE programs and their entrepreneurial attitudes, knowledge, skills, and behaviors. However, such programs obviously also influence a wider set of stakeholders, such as the instructors themselves and, in the case of field projects, the 
individuals and organizations involved. For example, "real-life cases" where students work on various consultancy tasks (such as market validation studies). The impact of EE can be on entrepreneurial behavior of staff and lecturers, when teaching entrepreneurship influences academics to become engaged in it themselves (whether in commercializing research or in nonresearch-based entrepreneurial activity at the side of academic work). EE programs where students engage in market validation studies and so forth also expose students to the entrepreneurial community. This can be built into higher levels of our teaching model framework to examine stakeholder impact. For example, we can assess the value of EE to university faculty, donors/investors, and communities at Levels 3, 4, and 5 of our framework (cf. Duval-Couetil, 2013).

\section{CONCLUSIONS}

While confirming the weaknesses in EE impact studies (e.g., dominance on lower level attitudinal and intentionality impact measures, and a lack of key detail concerning pedagogy), we also identify three main ways of moving forward. First, as indicated in Table 3, we add value by providing an up-to-date and empirically rooted call for future research in higher education. Second, by applying a teaching model framework, we offer several intriguing and underemphasized suggestions for improving EE research. Last and relatedly, we provide some critical insights into the reasons for the contradictory findings in $\mathrm{EE}$ research (e.g., rority of cross-cultural, gender-specific and pedagogical-comparison research) that can be further teased out through single studies/interventions, so we can understand how EE really works in theory and practice.

\section{REFERENCES}

Abaho, E., Olomi, D. R., \& Urassa, G. C. 2015. Students' entrepreneurial self-efficacy: Does the teaching method matter? Education + Training, 57(8/9): 908-923.

Ahmed, I., Nawaz, M. M., Ahmad, Z., Shaukat, M. Z., Usman, A., \& Rehman, W. 2010. Determinants of students' entrepreneurial career intentions: Evidence from business graduates. European Journal of Social Sciences, 15(2): 14-22.

Alarape, A. A. 2007. Entrepreneurship programs, operational efficiency and growth of small businesses. Journal of Enterprising Communities: People and Places in the Global Economy, 1(3): 222-239.

Almobaireek, W. N., \& Manolova, T. S. 2012. Who wants to be an entrepreneur? Entrepreneurial intentions among Saudi university students. African Journal of Business Management, 6(11): 4029-4040.
Armstrong, C. E. 2014. I meant to do that! Manipulating entrepreneurial intentions through the power of simple plans. Journal of Small Business and Enterprise Development, 21(4): 638-652.

Asslam, T. M., Awan, A. S., \& Khan, T. M. 2012. Entrepreneurial intentions among university students of Punjab, a province of Pakistan. International Journal of Humanities and Social Science, 2(14): 114-120.

Azim, M. T., \& Akbar, M. M. 2010. Entrepreneurship education in Bangladesh: A study based on program inputs. South Asian Journal of Management, 17(4): 21-36.

Bae, T. J., Qian, S., Miao, C., \& Fiet, J. O. 2014. The relationship between entrepreneurship education and entrepreneurial intentions: A meta-analytic review. Entrepreneurship Theory and Practice, 38(2): 217-254.

Bakotic, D., \& Kruzic, D. 2010. Students' perceptions and intentions towards entrepreneurship: The empirical findings from Croatia. The Business Review, Cambridge, 14(2): 209-215.

Barakat, S., Boddington, M., \& Vyakarnam, S. 2014. Measuring entrepreneurial self-efficacy to understand the impact of creative activities for learning innovation. International Journal of Management Education, 12(3): 456-468.

Baptista, R., \& Naia, A. 2015. Entrepreneurship education: A selective examination of the literature. Foundations and Trends in Entrepreneurship, 11(5): 337-426.

Basu, A. 2010. Comparing entrepreneurial intentions among students: The role of education and ethnic origin. AIMS International Journal of Management, 4(3): 163-176.

Béchard, J. P., \& Grégoire, D. 2005. Understanding teaching models in entrepreneurship for higher education. In P. Kÿro, \& C. Carrier (Eds.), The dynamics of learning entrepreneurship in a cross-cultural university context: 104-134. Tampere, Finland: Faculty of Education, University of Tampere.

Béchard, J. P., \& Grégoire, D. 2007. Archetypes of pedagogical innovation for entrepreneurship education: Model and illustrations. In A. Fayolle (Ed.), Handbook of research in entrepreneurship education: Vol. 1: 261-284. Cheltenham, UK: Edward Elgar Publishing.

Bell, R. 2015. Developing the next generation of entrepreneurs: Giving students the opportunity to gain experience and thrive. International Journal of Management Education, 13(1): 37-47.

Bernhofer, L., \& Han, Z. 2014. Contextual factors and their effects on future entrepreneurs in China: A comparative study of entrepreneurial intentions. International Journal of Technology Management, 65(1-2-3-4): 125-150.

Block, Z., \& Stumpf, S. A. 1992. Entrepreneurship education research: Experience and challenge. In D. L. Sexton, \& J. D. Kasarda (Eds.), The state-of-the-art of entrepreneurship: 17-42. Boston, MA: PWS-Kent Publishing Company.

Bosma, N., Acs, Z. J., Autio, E., Coduras, A., \& Levine, J. 2008. 2008 Global Entrepreneurship Monitor Executive Report. Wellesley, MA \& London.

Boukamcha, F. 2015. Impact of training on entrepreneurial intention: An interactive cognitive perspective. European Business Review, 27(6): 593-616. 
Brink, T., \& Madsen, S. O. 2015. Entrepreneurial learning requires action on the meaning generated. International Journal of Entrepreneurial Behaviour \& Research, 21(5): 650-672.

Burrows, K., \& Wragg, N. 2013. Introducing enterprise. Research into the practical aspects of introducing innovative enterprise schemes as extra curricula activities in higher education. Higher Education. Skills and Work-Based Learning, 3(3): 168-179.

Byabashaija, W., \& Katono, I. 2011. The impact of college entrepreneurial education on entrepreneurial attitudes and intention to start a business in Uganda. Journal of Developmental Entrepreneurship, 16(1): 127-144.

Canziani, B., Welsh, D. H. B., Hsieh, Y, \& Tullar, W. 2015. What pedagogical methods impact students' entrepreneurial propensity? Journal of Small Business Strategy, 25(2): 11-42.

Cardon, M. S., Wincent, J., Singh, J., \& Drnovsek, M. 2009. The nature and experience of entrepreneurial passion. Academy of Management Review, 34(3): 511-532.

Cardon, M. S., Foo, M., Shepherd, D., \& Wiklund, J. 2012. Exploring the heart: Entrepreneurial emotion is a hot topic. Entrepreneurship Theory and Practice, 36(1): 1-10.

Chang, J. Y. C., Benamraoui, A., \& Rieple, A. 2014. Stimulating learning about social entrepreneurship through income generation projects. International Journal of Entrepreneurial Behaviour \& Research, 20(5): 417-437.

Chang, J., \& Rieple, A. 2013. Assessing students' entrepreneurial skills development in live projects. Journal of Small Business and Enterprise Development, 20(1): 225-241.

Cheng, Y. M., Chan, S. W., \& Mahmood, A. 2009. The effectiveness of entrepreneurship education in Malaysia. Education + Training, 51(7): 555-566.

Coduras, A., Urbano, D., Rojas, Á., \& Martínez, S. 2008. The relationship between university support to entrepreneurship with entrepreneurial activity in Spain: A GEM data based analysis. International Advances in Economic Research, 14(4): 395-406.

Collins, L. A., Smith, A. J., \& Hannon, P. D. 2006. Discovering entrepreneurship: An exploration of a tripartite approach to developing entrepreneurial capacities. Journal of European Industrial Training, 30(3): 188-205.

Connolly, R., O'Gorman, B., \& Bogue, J. 2006. An exploratory study of the process by which recent graduate entrepreneurs (RGEs) become self-employed. Irish Journal of Management, 26(2): 185-210.

Cooper, H. M. 1989. Integrating research: A guide for literature reviews, (2nd ed.). Thousand Oaks, CA; London: Sage Publications.

Crane, F. G. 2014. Measuring and enhancing dispositional optimism and entrepreneurial intent in the entrepreneurial classroom: An Bahamian study. Journal of the Academy of Business Education, 15: 94-104.

Crane, F., \& Meyer, M. 2007. Teaching dispositional optimism in the entrepreneurial classroom. International Journal of Entrepreneurship Education, 5: 163-174.

Cruz, N. M., Escudero, A. I. R., Barahona, J. H., \& Leitao, F. S. 2009. The effect of entrepreneurship education programmes on satisfaction with innovation behaviour and performance. Journal of European Industrial Training, 33(3): 198-214.

Daghbashyan, Z., \& Hơrsman, B. 2014. University choice and entrepreneurship. Small Business Economics, 42(4): 729-746.

De Clercq, D., Honig, B., \& Martin, B. 2013. The roles of learning orientation and passion for work in the formation of entrepreneurial intention. International Small Business Journal, 31(6): 652-676.

De George, J. M., \& Fayolle, A. 2008. Is entrepreneurial intention stable through time? First insights from a sample of French students. International Journal of Entrepreneurship and Small Business, 5(1): 7-27.

DeTienne, D. R., \& Chandler, G. N. 2004. Opportunity identification and its role in the entrepreneurial classroom: A pedagogical approach and empirical test. Academy of Management Learning \& Education, 3(3): 242-257.

Díaz-Casero, J. C., Hernóndez-Mogollon, R., \& Roldán, J. L. 2012. A structural model of the antecedents to entrepreneurial capacity. International Small Business Journal, 30(8): 850-872.

Dickson, P. H., Solomon, G. T., \& Weaver, K. M. 2008. Entrepreneurial selection and success: Does education matter? Journal of Small Business and Enterprise Development, 15(2): 239-258.

Dominguinhos, P. M. C., \& Carvalho, L. M. C. 2009. Promoting business creation through real world experience: Projecto Começar. Education + Training, 51(2): 150-169.

Donnellon, A., Ollila, S., \& Middleton, K. W. 2014. Constructing entrepreneurial identity in entrepreneurship education. International Journal of Management Education, 12(3): 490-499.

Dutta, D. K., Li, J., \& Merenda, M. 2010. Fostering entrepreneurship: Impact of specialization and diversity in education. The International Entrepreneurship and Management Journal, 7(2): 163-179.

Duval-Couetil, N. 2013. Assessing the impact of entrepreneurship education programs: Challenges and approaches. Journal of Small Business Management, 51(3): 394-409.

Faoite, D. D., Henry, C., Johnston, K., \& Sijde, P. d. 2004. Entrepreneurs' attitudes to training and support initiatives: Evidence from Ireland and The Netherlands. Journal of Small Business and Enterprise Development, 11(4): 440-448.

Farashah, A. D. F. 2013. The process of impact of entrepreneurship education and training on entrepreneurship perception and intention: Study of educational system of Iran. Education + Training, 55(8/9): 868-885.

Fayolle, A. 2013. Personal views on the future of entrepreneurship education. Entrepreneurship and Regional Development, 25(7-8): 692-701.

Fayolle, A., \& Gailly, B. 2008. From craft to science: Teaching models and learning processes in entrepreneurship education. Journal of European Industrial Training, 32(7): 569-593.

Fayolle, A., \& Gailly, B. 2015. The impact of entrepreneurship education on entrepreneurial attitudes and intention: Hysteresis and persistence. Journal of Small Business Management, 53(1): 75-93.

Fayolle, A., Gailly, B., \& Lassas-Clerc, N. 2006a. Assessing the impact of entrepreneurship education programmes: A new methodology. Journal of European Industrial Training, 30(9): 701-720. 
Fayolle, A., Gailly, B., \& Lassas-Clerc, N. 2006b. Effect and countereffect of entrepreneurship education and social context on student's intentions. Estudios de Economía Aplicada, 24(2): 509-524.

Fink, A. 2009. Conducting research literature reviews: From the Internet to paper, (3rd ed.). London, Los Angeles: SAGE.

Florin, J., Karri, R., \& Rossiter, N. 2007. Fostering entrepreneurial drive in business education: An attitudinal approach. Journal of Management Education, 31(1): 17-42.

Franco, M., Haase, H., \& Lautenschläger, A. 2010. Students' entrepreneurial intentions: An inter-regional comparison. Education + Training, 52(4): 260-275.

Fretschner, M., \& Weber, S. 2013. Measuring and understanding the effects of entrepreneurial awareness education. Journal of Small Business Management, 51(3): 410-428.

Friedrich, C., \& Visser, K. 2006. Building human copital in difficult environments: An empirical study of entrepreneurship education, self-esteem, and achievement in South Africa. Developmental Entrepreneurship: Adversity, Risk, and Isolation, 5: 355-378.

Galloway, L., Anderson, M., Brown, W., \& Wilson, L. 2005. Enterprise skills for the economy. Education + Training, 47(1): 7-17.

Garalis, A., \& Strazdiene, G. 2007. Entrepreneurial skills development via simulation business enterprise. Socialiniai Tyrimai, 10: 39-48.

Garavan, T. N., \& O'Cinneide, B. 1994. Entrepreneurship education and training programmes: A review and evaluation Part l. Journal of European Industrial Training, 18(8): 3-12.

Gerba, D. T. 2012. Impact of entrepreneurship education on entrepreneurial intentions of business and engineering students in Ethiopia. African Journal of Economic and Management Studies, 3(2): 258-277.

Gielnik, M. M., et al. 2015. Action and action-regulation in entrepreneurship: Evaluating a student training for promoting entrepreneurship. Academy of Management Learning \& Education, 14(1): 69-94.

Gilbert, D. H. 2012. From chalk and talk to walking the walk: Facilitating dynamic learning contexts for entrepreneurship students in fast-tracking innovations. Education + Training, 54(2/3): 152-166.

Gondim, G. M. S., \& Mutti, C. 2011. Affections in learning situations: A study of an entrepreneurship skills development course. Journal of Workplace Learning, 23(3): 195-208.

Gordon, I., Hamilton, E., \& Jack, S. 2012. A study of a university-led entrepreneurship education programme for small business owner/managers. Entrepreneurship and Regional Development, 24(9-10): 767-805.

Greene, F. J., \& Saridakis, G. 2008. The role of higher education skills and support in graduate self-employment. Studies in Higher Education, 33(6): 653-672.

Greene, P. G., Katz, J. A., \& Johannisson, B. 2004. Entrepreneurship education. Academy of Management Learning \& Education, 3: $238-241$.

Groenewald, D. 2012. Assessment of teaching corporate entrepreneurship to master's level students. African Journal of Business Management, 6(7): 2484-2497.

Gundry, L. K., Ofstein, L. F., \& Kickul, J. R. 2014. Seeing around corners: How creativity skills in entrepreneurship education influence innovation in business. International Journal of Management Education, 12(3): 529-538.

Hamidi, D. Y., Wennberg, K., \& Berglund, H. 2008. Creativity in entrepreneurship education. Journal of Small Business and Enterprise Development, 15(2): 304-320.

Harms, R. 2015. Self-regulated learning, team learning and project performance in entrepreneurship education: Learning in a lean startup environment. Technological Forecasting and Social Change, 100: 21-28.

Harris, M. L., \& Gibson, S. G. 2008. Examining the entrepreneurial attitudes of US business students. Education + Training, 50(7): 568-581.

Horris, M. L., Gibson, S. G., \& Taylor, S. R. 2007. Examining the impact of small business institute participation on entrepreneurial attitudes. Journal of Small Business Strategy, 18(2): 57-76.

Harvey, C., Kelly, A., Morris, H., \& Rowlinson, M. 2010. The Association of Business Schools (ABS): Academic Journal Quality Guide Version 4. UK: ABS.

Hattab, H. W. 2014. Impact of entrepreneurship education on entrepreneurial intentions of university students in Egypt. The Journal of Entrepreneurship, 23(1): 1-18.

Hegarty, C. 2006. It's not an exact science: Teaching entrepreneurship in Northern Ireland. Education + Training, 48(5): 322-335.

Heinonen, J., Hytti, U., \& Stenholm, P. 2011. The role of creativity in opportunity search and business idea creation. Education + Training, 53(8/9): 659-672.

Henry, C., Hill, F. M., \& Leitch, C. M. 2003. Entrepreneurship education and training. Aldershot, Great Britain: Ashgate.

Henry, C., Hill, F. M., \& Leitch, C. M. 2005. Entrepreneurship education and training: Can entrepreneurship be taught? Education + Training, 47: 98-111.

Henry, C., Hill, F. M., \& Leitch, C. M. 2004. The effectiveness of training for new business creation. A longitudinal study. International Small Business Journal, 22(3): 249-271.

Heuer, A., \& Kolvereid, L. 2014. Education in entrepreneurship and the Theory of Planned Behavior. European Journal of Training and Development, 38(6): 506-523.

Hietanen, L. 2015. Facilitating employees' and students' process towards nascent entrepreneurship. Education + Training, 57(8/9): 964-976.

Hofstede, G. H. 2003. Culture's consequences: Comparing values, behaviors, institutions, and organizations across nations. Southand Oaks, CA: Sage Publications.

Hussain, J. G., Scott, J. M., \& Matlay, H. 2010. The impact of entrepreneurship education on succession in ethnic minority family firms. Education + Training, 52(8/9): 643-659.

Hytti, U., Stenholm, P., Heinonen, J., \& Seikkula-Leino, J. 2010. Perceived learning outcomes in entrepreneurship education: The impact of student motivation and team behaviour. Education + Training, 52(8/9): 587-606.

Idogho, P. O., \& Barr, A. A. 2011. Entrepreneurship education and small-scale business management skill development among students of Auchi Polytechnic Auchi, Edo State, Nigeria. International Journal of Business and Management, 6(3): 284-288. 
Ismail, M., Khalid, S.A., Othman, M., Jusoff, H.K., Rahman, N.A., \& Kassim, K.M., 2009. Entrepreneurial intention among Malaysian undergraduates. International Journal of Business and Management, 4(10): 54-60.

Izquierdo, E., \& Buelens, M. 2011. Competing models of entrepreneurial intentions: The influence of entrepreneurial self-efficacy and attitudes. International Journal of Entrepreneurship and Small Business, 13(1): 75-91.

Jack, S. L., \& Anderson, R. 1998. Entrepreneurship education within the condition of entreprenology. Paper presented at the Proceedings of the Conference on Enterprise and Learning, Aberdeen, Scotland.

Jansen, S., van de Zande, T., Brinkkemper, S., Stam, E., \& Varma, V. 2015. How education, stimulation, and incubation encourage student entrepreneurship: Observations from MIT, IIIT, and Utrecht University. International Journal of Management Education, 13(2): 170-181.

Joensuu, S., Viljamaa, A., Varamäki, E., \& Tornikoski, E. 2013. Development of entrepreneurial intention in higher education and the effect of gender: A latent growth curve analysis. Education + Training, 55(8/9): 781-803.

Jones, A., \& Jones, P. 2011. "Making an impact": A profile of a business planning competition in a university. Education + Training, 53(8/9): 704-721.

Jones, P., Jones, A., Packham, G., \& Miller, C. 2008. Student attitudes towards enterprise education in Poland: A positive impact. Education + Training, 50(7): 597-614.

Jones, P., Miller, C., Jones, A., Packham, G., Pickernell, D., \& Zbierowski, P. 2011. Attitudes and motivations of Polish students towards entrepreneurial activity. Education + Training, 53(5): 416-432.

Karimi, S., Biemans, H. J. A., Lans, T., Chizari, M., \& Mulder, M. 2016. The impact of entrepreneurship education: A study of Iranian students' entrepreneurial intentions and opportunity identification. Journal of Small Business Management, 54(1): 187-209.

Karlsson, T., \& Moberg, K. 2013. Improving perceived entrepreneurial abilities through education: Exploratory testing of an entrepreneurial self efficacy scale in a pre-post setting. International Journal of Management Education, 11(1): 1-11.

Kassean, H., Vanevenhoven, J., Liguori, E., \& Winkel, D. E. 2015. Entrepreneurship education: A need for reflection, real-world experience and action. International Journal of Entrepreneurial Behaviour \& Research, 21(5): 690-708.

Keat, O. Y., Selvarajah, C., \& Meyer, D. 2011. Inclination towards entrepreneurship among university students: An empirical study of Malaysian university students. International Journal of Business and Social Science, 2(4): 206-220.

Kenny, B. 2015. Meeting the entrepreneurial learning needs of professional athletes in career transition. International Journal of Entrepreneurial Behaviour \& Research, 21(2): 175-196.

Kirby, D. A., \& Humayun, H. 2013. Outcomes of an entrepreneurship education programme: An empirical study in Egypt. International Journal of Management, 30(3): 23-35.

Kirby, D. A., \& Ibrahim, N. 2011. Entrepreneurship education and the creation of an enterprise culture: Provisional results from an experiment in Egypt. The International Entrepreneurship and Management Journal, 7(2): 181-193.

Kirkpatrick, D. L. 1959. Techniques for evaluating training programs. Journal of the American Society of Training Directors, 13: 3-26.

Kirkwood, J., Dwyer, K., \& Gray, B. 2014. Students' reflections on the value of an entrepreneurship education. International Journal of Management Education, 12(3): 307-316.

Klapper, R. G. 2014. A role for George Kelly's repertory grids in entrepreneurship education? Evidence from the French and Polish context. International Journal of Management Education, 12(3): 407-421.

Krueger, N. F. 2007. What lies beneath? The experiential essence of entrepreneurial thinking. Entrepreneurship Theory and Practice, 31(1): 123-138.

Krueger, N. 2015. What do students learn from entrepreneurship education? Entrepreneurship360 thematic paper. Paris, France: OECD.

Krueger, N., Liñón, F., \& Nabi, G. 2013. Cultural values and entrepreneurship. Entrepreneurship and Regional Development, 25(9-10): 703-707.

Kuratko, D. F. 2005. The emergence of entrepreneurship education: Development, trends, and challenges. Entrepreneurship Theory and Practice, 29(5): 577-598.

Lackéus, M. 2014. An emotion based approach to assessing entrepreneurial education. International Journal of Management Education, 12(3): 374-396.

Lackéus, M. 2015. Entrepreneurship in education-What, why, when, how. Trento, Italy: Background paper for OECD-LEED.

Lanero, A., Vózquez, J. L., Gutiérrez, P., \& García, M. P. 2011. The impact of entrepreneurship education in European universities: An intention-based approach analyzed in the Spanish area. International Review on Public and Nonprofit Marketing, 8(2): 111-130.

Lange, J., Marram, E., Jawahar, A. S., Yong, W., \& Bygrave, W. 2014. Does an entrepreneurship education have lasting value? A study of careers of 3,775 alumni. Journal of Business and Entrepreneurship, 25(2): 1-31.

Lans, T., Gulikers, J., \& Batterink, M. 2013. Moving beyond traditional measures of entrepreneurial intentions in a study among life-sciences students in The Netherlands. Research in Post-Compulsory Education, 15(3): 259-274.

Laviolette, E. M., Radu Lefebvre, M., \& Brunel, O. 2012. The impact of story bound entrepreneurial role models on self-efficacy and entrepreneurial intention. International Journal of Entrepreneurial Behaviour \& Research, 18(6): 720742.

Lean, J. 2012. Preparing for an uncertain future, the enterprising $\mathrm{PhD}$ student. Journal of Small Business and Enterprise Development, 19(3): 532-548.

Lee, S. M., Chang, D., \& Lim, S.-B. 2005. Impact of entrepreneurship education: A comparative study of the US and Korea. The International Entrepreneurship and Management Journal, l(1): 27-43.

Li, Z., \& Liu, Y. 2011. Entrepreneurship education and employment performance: An empirical study in Chinese university. Journal of Chinese Entrepreneurship, 3(3): 195-203. 
Lima, E., Lopes, R. M., Nassif, V., \& da Silva, D. 2015. Opportunities to improve entrepreneurship education: Contributions considering Brazilian challenges. Journal of Small Business Management, 53(4): 1033-1051.

Liñón, F. 2004. 2004. Intention-based models of entrepreneurship education: 11-35. Urbino, Italy: Piccola Impresa/Small Business.

Löbler, H. 2006. Learning entrepreneurship from a constructivist perspective. Technology Analysis and Strategic Management, 18(1): 19-38.

Lourenço, F., \& Jayawarna, D. 2011. Enterprise education: The effect of creativity on training outcomes. International Journal of Entrepreneurial Behaviour \& Research, 17(3): 224-244.

Lourenço, F., Jones, O., \& Jayawarna, D. 2013. Promoting sustainable development: The role of entrepreneurship education. International Small Business Journal, 31(8): 841-865.

Man, T. W. Y., \& Farquharson, M. 2015. Psychological ownership in team-based entrepreneurship education activities. International Journal of Entrepreneurial Behaviour \& Research, 21(4): 600-621.

Martin, B. C., McNally, J. J., \& Kay, M. J. 2013. Examining the formation of human capital in entrepreneurship: A metaanalysis of entrepreneurship education outcomes. Journal of Business Venturing, 28(2): 211-224.

Matlay, H. 2008. The impact of entrepreneurship education on entrepreneurial outcomes. Journal of Small Business and Enterprise Development, 15(2): 382-396.

Matlay, H. 2011. The influence of stakeholders on developing enterprising graduates in UK HEIs. International Journal of Entrepreneurial Behaviour \& Research, 17(2): 166-182.

McAlexander, J., Nelson, R., \& Bates, C. 2009. Developing an entrepreneurial education in a residential college: An exploratory case study. New England Journal of Entrepreneurship, 12(2): 1-14.

McCrea, E. A. 2013. Adding to the pedagogical portfolio: Launching a student business in a semester course. New England Journal of Entrepreneurship, 16(1): 31-39.

Mentoor, E. R., \& Friedrich, C. 2007. Is entrepreneurial education at South African universities successful? An empirical example. Industry and Higher Education, 21(3): 221-232.

Miller, B. K., Bell, J. D., Palmer, M., \& Gonzalez, A. 2009. Predictors of entrepreneurial intentions: A quasi-experiment comparing students enrolled in introductory management and entrepreneurship classes. Journal of Business and Entrepreneurship, 21(2): 39-62.

Millman, C., Matlay, H., \& Liu, F. 2008. Entrepreneurship education in China: A case study approach. Journal of Small Business and Enterprise Development, 15(4): 802-815.

Mohamad, N., Lim, H.-E., Yusof, N., Kassim, M., \& Abdullah, H. 2014. Estimating the choice of entrepreneurship as a career. The case of University Utara. International Journal of Business and Society, 15(1): 65-80.

Mohamed, Z., Rezai, G., Nasir Shamsudin, M., \& Mu'az Mahmud, M. 2012. Enhancing young graduates' intention towards entrepreneurship development in Malaysia. Education + Training, 54(7): 605-618.

Morris, M. H., Webb, J. W., Fu, J., \& Singhal, S. 2013. A competencybased perspective on entrepreneurship education: Conceptual and empirical insights. Journal of Small Business Management, 51(3): 352-369.

Mueller, S., \& Anderson, A. R. 2014. Understanding the entrepreneurial learning process and its impact on students' personal development: A European perspective. International Journal of Management Education, 12(3): 500-511.

Munoz, C. A., Mosey, S., \& Binks, M. 2011. Developing opportunityidentification capabilities in the classroom: Visual evidence for changing mental frames. Academy of Management Learning \& Education, 10(2): 277-295.

Muofhe, N. J., \& Du Toit, W. F. 2011. Entrepreneurial education's and entrepreneurial role models' influence on career choice: Original research. SA Journal of Human Resource Management, 9(1): 1-15.

Nabi, G., \& Liñón, F. 2011. Graduate entrepreneurship in the developing world: Intentions, education and development. Education + Training, 53(5): 325-334.

Neergaard, H., Tanggaard, L., Krueger, N., \& Robinson, S. 2012. Pedagogical interventions in entrepreneurship from behaviorism to existential learning. Proceedings. Dublin, Ireland: Institute for Small Business and Entrepreneurship.

Newbold, K. F., Jr., \& Erwin, T. D. 2014. The education of entrepreneurs: An instrument to measure entrepreneurial development. Journal of Business and Entrepreneurship, 26(1): 141-178.

Ohland, M. W., Frillman, S. A., Zhang, G., Brawner, C. E., \& Miller, T. K. 2004. the effect of an entrepreneurship program on GPA and retention. Journal of Engineering Education, 93(4): 293-301.

Packham, G., Jones, P., Miller, C., Pickernell, D., \& Thomas, B. 2010. Attitudes towards entrepreneurship education: A comparative analysis. Education + Training, 52(8/9): 568-586.

Pei-Lee, T., \& Chen-Chen, Y. 2008. Multimedia University's experience in fostering and supporting undergraduate student technopreneurship programs in a triple helix model. Journal of Technology Management in China, 3(1): 94-108.

Petridou, E., \& Sarri, K. 2011. Developing "potential entrepreneurs" in higher education institutes. Journal of Enterprising Culture, 19(1): 79-99.

Piperopoulos, P., \& Dimov, D. 2015. Burst bubbles or build steam? entrepreneurship education, entrepreneurial self-efficacy, and entrepreneurial intentions. Journal of Small Business Management, 53(4): 970-985.

Pittaway, L. A., Gazzord, J., Shore, A., \& Williamson, T. 2015. Student clubs: Experiences in entrepreneurial learning. Entrepreneurship and Regional Development, 27(3-4): 127-153.

Pittaway, L., \& Cope, J. 2007. Entrepreneurship education a systematic review of the evidence. International Small Business Journal, 25(5): 479-510.

Pittaway, L., Rodriguez-Falcon, E., Aiyegbayo, O., \& King, A. 2011. The role of entrepreneurship clubs and societies in entrepreneurial learning. International Small Business Journal, 29(1): 37-57.

Poblete, C., \& Amoros, J. E. 2013. University support in the development of regional entrepreneurial activity: An exploratory study from Chile. Investigaciones Regionales (26): 159-177. 
Premand, P., Brodmann, S., Almeida, R., Grun, R., \& Barouni, M. 2016. Entrepreneurship education and entry into selfemployment among university graduates. World Development, 77: 311-327.

Rae, D., \& Woodier-Harris, N. 2012. International entrepreneurship education: Postgraduate business student experiences of entrepreneurship education. Education + Training, 54(8/9): 639-656.

Raposo, M. L. B., Ferreira, J. J. M., do Paço, A. M. F., \& Rodrigues, R. J. G. 2008. Propensity to firm creation: Empirical research using structural equations. The International Entrepreneurship and Management Journal, 4(4): 485-504.

Rauch, A., \& Hulsink, W. 2015. Putting entrepreneurship education where the intention to act lies: An investigation into the impact of entrepreneurship education on entrepreneurial behavior. Academy of Management Learning \& Education, 14(2): 187-204.

Rideout, E. C., \& Gray, D. O. 2013. Does entrepreneurship education really work? A review and methodological critique of the empirical literature on the effects of university-based entrepreneurship education. Journal of Small Business Management, 51(3): 329-351.

Saeed, S., Yousafzai, S. Y., Yani-De-Soriano, M., \& Muffatto, M. 2015. The role of perceived university support in the formation of students' entrepreneurial intention. Journal of Small Business Management, 53(4): 1127-1145.

Sónchez, J. C. 2011. University training for entrepreneurial competencies: Its impact on intention of venture creation. The International Entrepreneurship and Management Journal, 7(2): 239-254.

Schwartz, S. H. 2004. Mapping and interpreting cultural differences around the world. In H. Vinken, J. Soeters, \& P. Ester, (Eds.), Comparing cultures, dimensions of culture in a comparative perspective: 43-73. Leiden, The Netherlands: Brill.

Shariff, A. M., Hasan, N. F. H. N., Mohamad, Z., \& Jusoff, K. 2010. The relationship between active teaching and learning with graduate's entrepreneurial intention and interest. Interdisciplinary Journal of Contemporary Research in Business, 2(1): 283-294.

Shinnar, R. S., Hsu, D. K., \& Powell, B. C. 2014. Self-efficacy, entrepreneurial intentions, and gender: Assessing the impact of entrepreneurship education longitudinally. International Journal of Management Education, 12(3): 561-570.

Shneor, R., Camgöz, S. M., \& Karapinar, P. B. 2013. The interaction between culture and sex in the formation of entrepreneurial intentions. Entrepreneurship and Regional Development, 25(9-10): 781-803.

Smith, K., \& Beasley, M. 2011. Graduate entrepreneurs: Intentions, barriers and solutions. Education + Training, 53(8/9): 722-740.

Solesvik, M. Z. 2013. Entrepreneurial motivations and intentions: Investigating the role of education major. Education + Training, 55(3): 253-271.

Solesvik, M. Z., Westhead, P., Matlay, H., \& Parsyak, V. N. 2013. Entrepreneurial assets and mindsets. Education + Training, 55(8/9): 748-762.
Solesvik, M., Westhead, P., \& Matlay, H. 2014. Cultural factors and entrepreneurial intention: The role of entrepreneurship education. Education + Training, 56(8/9): 680-696.

Solomon, G. 2007. An examination of entrepreneurship education in the United States. Journal of Small Business and Enterprise Development, 14: 168-182.

Souitaris, V., Zerbinati, S., \& Al-Laham, A. 2007. Do entrepreneurship programmes raise entrepreneurial intention of science and engineering students? The effect of learning, inspiration and resources. Journal of Business Venturing, 22(4): 566-591.

Stamboulis, Y., \& Barlas, A. 2014. Entrepreneurship education impact on student attitudes. International Journal of Management Education, 12(3): 365-373.

Støren, A. L. 2014. Entrepreneurship in higher education: Impacts on graduates' entrepreneurial intentions, activity and learning outcome. Education + Training, 56(8/9): 795-813.

Tang, S., \& Ng, C. F. 2006. A problem-based learning approach to entrepreneurship education. Education + Training, 48(6): $416-428$.

Thompson, P., Jones-Evans, D., \& Kwong, C. C. Y. 2010. Education and entrepreneurial activity: A comparison of White and South Asian Men. International Small Business Journal, 28(2): 147-162.

Thursby, M. C., Fuller, A. W., \& Thursby, J. 2009. An integrated approach to educating professionals for careers in innovation. Academy of Management Learning \& Education, 8(3): 389-405.

Toledano, N., \& Urbano, D. 2008. Promoting entrepreneurial mindsets at universities: A case study in the South of Spain. European Journal of International Management, 2(4): 382-399.

Tounés, A., Lassas-Clerc, N., \& Fayolle, A. 2014. Perceived entrepreneurial competences tested by business plan pedagogies. International Journal of Entrepreneurship and Small Business, 21(4): 541-557.

Tranfield, D. R., Denyer, D., \& Smart, P. 2003. Towards a methodology for developing evidence-informed management knowledge by means of systematic review. British Journal of Management, 14: 207-222.

Turker, D., \& Selçuk, S. 2009. Which factors affect entrepreneurial intention of university students? Journal of European Industrial Training, 33(2): 142-159.

Ulvenblad, P., Berggren, E., \& Winborg, J. 2013. The role of entrepreneurship education and start-up experience for handling communication and liability of newness. International Journal of Entrepreneurial Behaviour \& Research, 19(2): 187-209.

Varamäki, E., Joensuu, S., Tornikoski, E., \& Viljamaa, A. 2015. The development of entrepreneurial potential among higher education students. Journal of Small Business and Enterprise Development, 22(3): 563-589.

Vincett, P. S., \& Farlow, S. 2008. "Start-a-Business": An experiment in education through entrepreneurship. Journal of Small Business and Enterprise Development, 15(2): 274-288.

Voisey, P., Gornall, L., Jones, P., \& Thomas, B. 2006. The measurement of success in a business incubation project. Journal of Small Business and Enterprise Development, 13(3): 454-468. 
Von Graevenitz, G., Horhoff, D., \& Weber, R. 2010. The effects of entrepreneurship education. Journal of Economic Behavior \& Organization, 76(1): 90-112.

Vorley, T., \& Williams, N. 2016. Not just dialling it in: Examining cognitive-based approaches in enterprise education using a smartphone application. Education + Training, 58(1): 45-60.

Walter, S. G., \& Dohse, D. 2012. Why mode and regional context matter for entrepreneurship education. Entrepreneurship and Regional Development, 24(9-10): 807-835.

Walter, S. G., Parboteeah, K. P., \& Walter, A. 2013. University departments and self-employment intentions of business students: A cross-level analysis. Entrepreneurship Theory and Practice, 37(2): 175-200.

Wang, C. L., \& Chugh, H. 2014. Entrepreneurial learning: Past research and future challenges. International Journal of Management Reviews, 16(1): 24-61.

Wang, Y., \& Verzat, C. 2011. Generalist or specific studies for engineering entrepreneurs? Comparison of French engineering students' trajectories in two different curricula. Journal of Small Business and Enterprise Development, 18(2): 366-383.

Watts, C. A., \& Wray, K. 2012. Using toolkits to achieve STEM enterprise learning outcomes. Education + Training, 54(4): 259-277.

Wee, K. N. L. 2004. A problem-based learning approach in entrepreneurship education: Promoting authentic entrepreneurial learning. International Journal of Technology Management, 28(7-8): 685-701.

Westhead, P., \& Solesvik, M. Z. 2015. Entrepreneurship education and entrepreneurial intention: Do female students benefit? International Small Business Journal, 34(8): 979-1003.

Wilson, F., Kickul, J., \& Marlino, D. 2007. Gender, entrepreneurial selfefficacy, and entrepreneurial career intentions: Implications for entrepreneurship education. Entrepreneurship Theory and Practice, 31(3): 387-406.

Wilson, F., Kickul, J., Marlino, D., Barbosa, S. D., \& Griffiths, M. D. 2009. An analysis of the role of gender and self-efficacy in developing female entrepreneurial interest and behavior. Journal of Developmental Entrepreneurship, 14(2): 105119.

Woodier-Harris, N. R. 2010. Evaluating the impact of SPEED on students' career choices: A pilot study. Education + Training, 52(6/7): 463-476.

Yaghmaei, O., Ardestani, H. S., Ghasemi, I., Baraeinezhad, S., \& Parsa, R. 2015. Relationship among influential factors of entrepreneurial intention: An associational study. Modern Applied Science, 9(9): 114-121.

Yusoff, M. N. H., Nasir, W. N. B. W., \& Zainol, F. A. B. 2012. Assessing the impact of knowledge of government business support services on propensity of new graduates to venture into business. International Journal of Business and Management, 7(16): 106-117.

Zainuddin, M. N., \& Rejab, M. R. M. 2010. Assessing "ME generation's" entrepreneurship degree programmes in Malaysia. Education + Training, 52(6/7): 508-527.

Zainuddin, M. N., Rahim, M. F. A., \& Rejab, M. R. M. 2012. Reconstruct creative destruction knowledge through creative disruption. On the Horizon, 20(1): 34-48.

Zhang, Y., Duysters, G., \& Cloodt, M. 2014. The role of entrepreneurship education as a predictor of university students' entrepreneurial intention. The International Entrepreneurship and Management Journal, 10(3): 623-641.

Zhao, H., Seibert, S. E., \& Hills, G. E. 2005. The mediating role of selfefficacy in the development of entrepreneurial intentions. The Journal of Applied Psychology, 90(6): 1265-1272.

Ghulam Nabi ( $\mathrm{PhD}$, University of Central Lancashire, UK) is a senior lecturer in entrepreneurship and organizational behavior, Manchester Metropolitan University Business School, UK. Current research interests include student-to-entrepreneur transition, entrepreneurial intentions, entrepreneurship education, and the role of mentoring in entrepreneurial development. Ghulam has published over 18 articles in leading international journals.

Francisco Liñón (PhD, University of Seville, Spain) is professor of entrepreneurship and innovation at Anglia Ruskin University (UK), and University of Seville. Francisco's main research interests include entrepreneurship as a process, entrepreneurial intentions, and culture's role in entrepreneurship. He has published over 25 articles in international journals and edited books.

Alain Fayolle ( $\mathrm{PhD}$, University of Lyon, France) is a professor and Research Centre director, EM Lyon Business School, France. Alain is also the Academy of Management ENT Division Chair. His research interests are entrepreneurship education, corporate entrepreneurship, entrepreneurial intention, and behavior.

Norris Krueger ( $\mathrm{PhD}$, The Ohio State University, US) is a senior research fellow of the Center for Management and Entrepreneurship, University of Phoenix. Norris is passionate about developing entrepreneurial thinking, the most cited author on entrepreneurial intentions, and is now researching deeper cognitive phenomena (e.g., "neuroentrepreneurship"). He is equally passionate about growing entrepreneurial ecosystems (Entrepreneurship Northwest; organized Startup Weekends, \& 1 Million Cups).

Andreas Walmsley (PhD, Leeds Beckett University, UK) is an associate professor at Plymouth University, UK. Andreas's current research revolves around entrepreneurship education, entrepreneurship in tourism and hospitality, and employment in the service industries. 
Copyright of Academy of Management Learning \& Education is the property of Academy of Management and its content may not be copied or emailed to multiple sites or posted to a

listserv without the copyright holder's express written permission. However, users may print, download, or email articles for individual use. 